\title{
Uma Justificação Democrática da Jurisdição Constitucional Brasileira e a Inconstitucionalidade da Lei $n^{\circ}$ 9.686/99
}

\section{Ollarcelo Atmdrade Cattoni de Oliveiva}

Mestre e Doutor em Direito Constitucional (UFMG), Professor Adjunto de Direito Processual Civil e de Teoria Geral do Processo (UFMG), Ex-Professor Adjunto de Processo Constitucional e de Teoria Geral do

Processo (PUC/MG), Professor Adjunto de Filosofia do Direito e de Hermenêutica e Argumentação Jurídica (PUC/MG), Presidente do Comitê de Ética na Pesquisa (PUC/MG), Membro do Conselho Estadual de Direitos Humanos da Secretaria de Estado da Justiça e Direitos Humanos de Minas Gerais, Membro da Comissão de Direitos Humanos da OAB/MG, Advogado.

"Se os juízes brasileiros abdicarem dessa autoridade (a de controlar a constitucionalidade dos atos do Congresso e do Executioo), a Constituição republicana ruirá lamentavelmente num esboroamento irreparível, construção magnífica, que desaba em momentos, mal lhe retiraram os simples. É que lhe terá faltado o que não depende da ciência do arquiteto: esse cimento que não se substitui, nem se cria, o elemento humano, a consciência jurídica e a energia moral,

De nada servirá ao povo que suas instituições baixem do céu, ou fossem diretamente plantadas por mãos divinas, se a terra, onde caem, não fosse capaz de produzir a inteireza de ânimo e a coragem do dever, a executar. O estadista constrói as garantias; mas se não houver homens no meneio da máquina, quem garantirá as garantias?

Não creio que seja chegada a crise extrema de leoantarmos esse grito de desespero; porque não posso convencer-me de que esse último apelo aos tribunais do meu país morra no deserto. É ainda um resto de fé que hoje os exoro, pai dirigindo-se a pais, senão em nome do interesse de nossa época, já no ocaso, ao menos no da de nossos filhos, condenados aos amargos dos frutos de nossas fraquezas. 'Recordai-vos, juizes', como dizia d'Aguesseau, 'que, se sois eleondos acima do povo, que vos circunda a tribunal, não é señ̃o para ficardes mais expostos aos olhares de todos. Vós julgais a sua causa, mas ele julga a vossa justiça; e tal é a fortuna, ou a desventura, de vossa condiçño, que não the podeis esconder nem a vossa virtude, nem os vossos defeitos'."

(Ruy Barbosa in A Constituição e os Actos Inconstitucionais do Congresso e do Executivo ante a Justiça Federal, em 31 de março de 1893)

\section{Introdução}

E

$\mathrm{m}$ fins de novembro de 2000, em seminário exemplarmente organizado pela Procuradoria da República em Minas Gerais, ${ }^{2}$ foi proposta a questão de se no marco do Estado Democrático de Direito seria adequado caracterizar a Jurisdição Constitucional como Poder Constituinte permanente, quando do exercício do controle de constitucionalidade e na garantia dos direitos fundamentais, refletindo preocupação

1 Texto inédito, apresentado parcialmente em palestra proferida no dia 17 de abril de 2001, na Faculdade Mineira de Direito, da Pontifícia Universidade Católica de Minas Gerais. Dedico este artigo aos caros Professores Doutores Aroldo Plínio Gonçalves, José Alfredo de Oliveira Baracho, Menelick de Carvalho Netto, José Luiz Quadros de MagaIhães e Rosemiro Pereira Leal, baluartes do Direito Constitucional e Processual Democráticos brasileiros.

2 Procuradoria da República em Minas Gerais, Seminário Jurisdição e Hermenêutica Constitucional, nov. de 2000. 
que se torna pertinente com a tentativa de inserção, no Direito Constitucional brasileiro, dos dispositivos da Lei no 9.868/99, que pretende descaracterizar o controle de constitucionalidade das leis, buscando transformar o Supremo Tribunal Federal num arremedo de Corte Constitucional européia.

A pergunta acerca de um possível caráter constituinte permanente da jurisdição constitucional, assim como a promulgação da Lei n⿳9 9.868/99, deita raízes mais profundas sobre quais seriam, afinal, sob o Estado Democrático de Direito, os pressupostos metodológicos e de legitimidade do controle jurisdicional de constitucionalidade das leis, no Direito Constitucional brasileiro.

De uma perspectiva analítica, o que ora se inquire pode ser problematizado, pelo menos, a partir de três pontos de vista: primeiramente, do ponto de vista teoréticohistórico e sociológico; segundo, do ponto de vista teorético-filosófico; e terceiro, do ponto de vista teórico-dogmático.

Esta reflexão está dividida em cinco partes. Na primeira, procuraremos tratar a questão, colocada de um ponto de vista teorético-histórico e sociológico, buscando caracterizar a jurisdição constitucional no marco da crise do Estado Social.

$\mathrm{Na}$ segunda, procuraremos reconstruir, de um ponto de vista teorético-filosófico, a partir da Teoria Discursiva do Direito e do Estado Democrático de Direito, ${ }^{3}$ uma justificação para a jurisdição constitucional que, a um só tempo, supera tanto os problemas advindos de sua compreensão sob o paradigma do Estado Social, quanto as suas idealizações empreendidas no contexto das tradições políticas liberal e republicana.

$\mathrm{Na}$ terceira, enfrentaremos o problema da reinterpretação da jurisdição constitucional de um ponto de vista teórico-dogmático. Trataremos, então, de dilemas do Direito Constitucional e Processual brasileiros. E procuraremos explicitar, através de duas digressões, a dimensão operacional de uma teoria do Direito constitucionalmente adequada ao paradigma do Estado Democrático do Direito, aqui, pressuposta.

Na quarta parte, pressupondo discussões até então avançadas, daremos continuidade ${ }^{4}$ a uma compreensão constitucio nalmente adequada da jurisdição constitucional, da jurisdição em matéria constitucional, no Brasil.

E, por fim, num quinto momento, faremos apontamentos críticos à tentativa de concentração do controle jurisdicional de constitucionalidade das leis que se pretende com a Lei no 9.868/99, a título de considerações finais.

\section{Ponto de vista teorético- histórico e sociológico}

Do ponto de vista teorético-histórico e sociológico, pode-se analisar a jurisdi-

3 HABERMAS, Jürgen. Facticidad y validez. Trad. Mauel Jiménez Redondo. Madri: Trotta, 1998.

4 Sobretudo em CATTONI DE OLIVEIRA, Marcelo Andrade. Devido processo legislativo. Belo Horizonte: Mandamentos, 2000, e CATTONI DE OLIVEIRA, Marcelo Andrade. Direito processual constitucional. Belo Horizonte: Mandamentos, 2001. 
ção constitucional no contexto da crise do Estado Social. No marco do paradigma do Estado Social, a jurisdição constitucional, independentemente do sistema jurídico concreto, assumiu o papel de um legislador concorrente ou ao menos subsidiário, na sua forma negativa ou positiva, no sentido da realização de uma suposta ordem concreta de valores, subjacente à ordem constitucional, que desenvolveria as convicções axiológicas, tidas como majoritárias, para não dizer homogêneas, na sociedade.

Assim, a jurisdição constitucional teria o papel de corrigir ou até mesmo de antecipar-se ao Legislativo, compreendendo o Direito no sentido da realização do que a nação corporificada no Estado entendesse como o bem-comum, materializado através de determinadas condições sociais e possibilidades políticas definidas no interior das burocracias. Nesse sentido, as normas constitucionais deveriam ser ponderadas a cada aplicação, enquanto consagradoras de bens e de valores a serem otimizados em face dos casos concretos. Questões tais como segurança nacional, paz e até mesmo liberdade e igualdade teriam de ser equacionadas segundo uma argumentação que pudesse explicitar o projeto de autorealização de uma comunidade concreta de cidadãos que buscasse o que é melhor para si, interpretando suas necessidades e potencialidades à luz de uma substância ético-cultural própria, a ser assumida e transformada de potência em ato, de gera- ção em geração. Aqui a jurisdição constitucional assumiria o lugar de um poder constituinte permanente de desenvolvimento de valores pressupostos à Constituição, limitando, dirigindo e antecipando-se ao Legislativo. ${ }^{5}$

Partindo-se, com razão, de uma imagem de sociedade descentrada, em que vários deuses e demônios, para usar uma metáfora weberiana, convivem e concorrem para o florescimento humano, essa visão paradigmática da jurisdição constitucional, excessivamente materializada, realizadora de modelos-padrão de bem-estar, é inconcebível. A tudo isso, acrescenta-se o déficit democrático de uma jurisdição cujos titulares não foram sequer eleitos pelos cidadãos e que assume o papel de um superpoder que interpreta a pretensa vontade ou intenção fundadora daqueles que legislativamente burilaram o Texto Constitucional. Instala-se, nesse sentido, uma disputa entre uma jurisdição de especialistas e um legislativo suposto representante do pensamento político majoritário de uma sociedade de massas. Afinal, quem teria razão, quanto à auto-realização da identidade cívica do corpo de cidadãos, o legislativo ou um tribunal especializado (ou todo o judiciário), na definição do melhor para uma dada sociedade?

Os movimentos de desobediência civil, ${ }^{6}$ quer pelo desarmamento, pela crítica a um sistema caduco de educação ou pela proteção do meio ambiente, vão procurar

5 CATTONI DE OLIVEIRA, Marcelo Andrade. Devido processo legislativo. Belo Horizonte: Mandamentos, 2000.

6 SALCEDO REPOLÊS, María Fernanda. "Pode a desobediência civil ser justificada sem se apelar para uma fundamentação última?" In Seminário de Filosofia Política - A Fundamentação e a Democracia. Belo Horizonte: Escola do Legislativo da Assembléia Legislativa do Estado de Minas Gerais, em 8 de outubro de 1998. 
questionar decisões que buscam legitimar o uso de tropas fora do território nacional, guerras imperialistas não declaradas, ações repressivas e violadoras dos direitos humanos, ou projetos econômicos não ecológicos desenvolvidos por parte de qualquer governo ou corporação latino-americanos, norte-americanos ou europeus, reclamando a falta de participação democrática e evidenciando a contradição entre um capitalismo selvagem e um regime político neocorporativo, distanciado e pouco permeável aos anseios da sociedade civil.

\section{Ponto de vista teorético- filosófico}

Apresentaremos, agora, a perspectiva filosófica, de um ponto de vista reconstrutivo. ${ }^{7}$ Qual a justificativa histórico-teorética da jurisdição constitucional?

Duas tradições do pensamento político democrático moderno pretendem apresentar respostas diferentes para tal indagação. A perspectiva liberal, que remonta a LOCKE, considera que a jurisdição constitucional deve impor limites à atividade legislativa no sentido de garantir a razoabilidade das decisões políticas, procurando garantir condições equânimes de negociação entre as diversas tendências políticas, a fim de, por um lado, fazer transparecer a posição política majoritária e, por outro, garantir os direitos fundamentais enquanto direitos individuais. A posição republicana, que remonta a ROUSSEAU, se vê na jurisdição constitucional alguma função, encara-a como pedagógica, no sentido da condução de uma educação/correção ética que assegure a realização dos valores supostamente subjacentes às normas constitucionais, em face de uma cidadania imatura, radicalizando a postura do bem-estar social. ${ }^{8}$

A postura filosófica aqui adotada pretende partir de pressupostos diferentes. Embora não tenha o mesmo receio liberal quanto à política, descarta o fundamento republicano único para a democracia (o fundamento ético homogêneo) e pretende encarar o pluralismo axiológico e cultural como uma questão central para as sociedades contemporâneas, sem, contudo, renunciar à dimensão dialógica da política deliberativa. Adota, assim, uma Teoria Discursiva da Democracia e do Direito, ${ }^{9}$ em que a perspectiva procedimental ultrapassa tanto a política como luta de interesses, como pressupõe o liberalismo, quanto a política enquanto auto-realização ética, como quer o republicanismo cívico. Entende que a política se baseia em razões de diferentes espectros, éticos, morais e pragmáticos, em que o peso dessas razões se resolve procedimentalmente e não a partir da imagem de um corpo efetivamente unido de cidadãos, como quer o

7 Segundo MANUEL JIMÉNEZ REDONDO, uma teoria que procede em termos reconstrutivos "reconstruye la idealidad inmanente a la facticidad de la realidad como aguijón y elemento de tensión operante en esa misma realidad" (Introducción a HABERMAS, Jürgen. Facticidad y validez. Sobre el derecho y el Estado democrático de derecho en términos de teoría del discurso. Trad. Jeménez Redondo. Madri: Trotta, 1998).

8 CATTONI DE OLIVEIRA, Marcelo Andrade. Devido processo legislativo. Belo Horizonte: Mandamentos, 2000.

9 HABERMAS, Jürgen. Facticidad y validez. Trad. Manuel Jiménez Redondo. Madri: Trotta, 1998. 
republicanismo, ou de um sistema político encarado à luz da economia de mercado, como quer o liberalismo. A participação democrática é discursiva e se garante através da permeabilidade do sistema político à opinião pública livre, pressupondo-se o controle público dos meios de comunicação formadores de pontos de vista políticos.

A tese aqui defendida é a de que a jurisdição constitucional, no exercício do controle de constitucionalidade, deve garantir o devido processo legislativo, o devido processo constitucional e os direitos fundamentais, no sentido de que constitucionalismo e democracia não são concorrentes, mas faces de uma mesma moeda: os direitos fundamentais são garantias de institucionalização de um processo legislativo democrático, fundado na autonomia jurídica, pública e privada, e realizador da pretensão jurídico-moderna, segundo a qual os destinatários das normas são seus próprios autores. ${ }^{10}$

Assim, embora a democracia exija uma jurisdição constitucional ofensiva, no sentido da tutela jurídica de direitos constitucionais garantidores de um processo legislativo democrático, essa não deve nem precisa ser uma guardiã republicana de pretensos valores ético-políticos tidos como homogêneos ou majoritários na sociedade, como, de fato, se comportou a jurisdição constitucional sob o paradigma do Estado Social. ${ }^{11}$

\section{Ponto de vista teórico- dogmático}

Como deve ser tratada a questão do ponto de vista de uma Teoria do Direito? Consideramos que a Teoria do Direito possui uma dimensão operacional, enquanto chave interpretativa do Direito, no caso, Constitucional vigente. ${ }^{12} \mathrm{E}$ então nos voltamos para o Direito Constitucional brasileiro, no sentido de uma interpretação/ operacionalização constitucionalmente adequada dos dispositivos normativos pátrios.

tema da jurisdição constitucional torna-se muito importante num país como o Brasil, com recorrentes momentos de inércia e de déficit de integração social que são tradicionalmente percebidos e interpretados por teorias jurídicas especializadas em questões normativas, como contrastes ou hiatos entre um Direito Constitucional que se pretende legítimo e realidades políticosociais e econômicas recalcitrantes, um ideal a ser buscado e uma crua realidade. Em momentos de grande agitação política, tal postura pode traduzir-se no mais autêntico dos protestos:

"Não sejamos ridículos. A Constituição de 1988 não está mais em vigor. É pura perda de tempo discutir se a conjunção e significa ou, se o caput de um artigo dita o sentido do parágrafo ou se o inciso tem precedência sobre a alínea. A

10 CATTONI DE OLIVEIRA, Marcelo Andrade. Devido Processo Legislativo. Belo Horizonte: Mandamentos, 2000.

11 HABERMAS, Jürgen. Facticidad y validez. Trad. Manuel Jiménez Redondo. Madri: Trotta, 1998.

12 CATTONI DE OLIVEIRA, Marcelo Andrade. Devido processo legislativo. Belo Horizonte: Mandamentos, 2000 e CATTONI DE OLIVEIRA, Marcelo Andrade. Direito processual constitucional. Belo Horizonte: Mandamentos: 2001. 
Constituição é hoje o que a Presidência quer que ela seja, sabendo-se que todas as vontades do Planalto são confirmadas pelo judiciário.

As Ordenações Filipinas, que vigoraram entre nós por muito tempo, cominavam dois tipos de pena capital: a morte natural e a espiritual. A primeira atingia o corpo; a segunda, a alma. $\mathrm{O}$ excomungado continuava a viver, mas só fisicamente: sua alma fora executada pela autoridade episcopal, com a ajuda do braço secular do Estado.

Algo semelhante aconteceu com nossa Carta. Ela continua a existir materialmente, seus exemplares podem ser adquiridos nas livrarias (na seção das obras de ficção, naturalmente), suas disposições são invocadas pelos profissionais do Direito no característico estilo boca de foro. Mas é um corpo sem alma. HITLER, afinal, não precisou revogar a Constituição de WEIMAR para instaurar na civilizada Alemanha a barbárie nazista: simplesmente relegou às traças aquele pedaço de papel.

A única razão de ser de uma Constituição é proteger a pessoa humana contra o abuso de poder dos governantes. Se ela é incapaz disso, porque o governo dita a interpretação de suas normas ou as revoga sem maiores formalidades, seria mais decente mudar a denominação - 'o Presidente da República, ouvido o Congresso Nacional e consultado o Supremo Tribunal Federal, resolve: a Constituição da República Federativa do Brasil passa a denominar-se regimento interno do governo'."'13
Com certeza, as tentativas bem sucedidas de viabilização de políticas governamentais através de reformas juridicamente discutíveis da Constituição e da legislação; o uso abusivo e descontrolado de medidas provisórias que está acarretando uma verdadeira redução do processo legislativo a uma função meramente legitimatória de políticas governamentais; e a omissão do Supremo Tribunal Federal quanto ao controle dos atos processuais legislativos com base em doutrinas tais como a dos atos políticos interna corporis e das matérias não-jurisdicionáveis, e, principalmente, na sua compreensão pseudoliberal dos estritos limites de sua legitimidade política para exercer um controle judicial mais efetivo de constitucionalidade e de regularidade da lei e do processo legislativo, muitas vezes reduzindo este último a uma dimensão eminentemente político-deliberativa desprovida de caráter de juridicidade; tudo isso, ainda somado às propostas que freqüentemente se apresentam de se proceder a uma revisão global da Constituição à margem da própria Constituição, termina por institucionalizar o sistemático desrespeito às normas constitucionais e regimentais, e a colocar em risco não somente os direitos das minorias parlamentares, mas a própria ordem democrático-constitucional.

$\bigcirc$ desrespeito institucionalizado ao que se poderia chamar de devido processo legislativo e constitucional, ao contrário de um pensamento governista que vê em tais atos apenas a vitória da vontade da maioria democrática 
do povo brasileiro, está a colocar em risco, dia após dia, o próprio regime democrático garantidor da autonomia pública e privada dos cidadãos.

Sobre o pano de fundo dessas questões é que colocamos o problema da necessidade de se reinterpretar a tarefa da jurisdição constitucional brasileira, em face do Direito Constitucional vigente, buscando, inclusive, superar o enfoque tradicional que, ao traçar uma dicotomia entre Direito e realidade, nada contribui, ao contrário, aprofunda os problemas de integração social que devemos enfrentar.

Mas, antes disso, a fim de explicitar a dimensão operacional de uma teoria do Direito constitucionalmente adequada ao Estado Democrático de Direito, necessária à reinterpretação da jurisdição constitucional no Brasil, propomos duas digressões:

Digressão 1: A dicotomia Direito Constitucional Processual e Direito Processual Constitucional: limites em face do modelo brasileiro de controle de constitucionalidade

Uma problemática importante, de antemão, é preciso superar: a dicotomia artificialmente construída entre Direto Constitucional Processual e Direito Processual Constitucional ou, simplesmente, processo constitucional, em face do modelo constitucional do processo brasileiro.

Com a ampla constitucionalização de princípios processuais, no passado construídos a partir da aplicação da legisla- ção processual, juristas brasileiros, seguindo as lições de autores alemães, introduziram na discussão constitucional e processual pátria a distinção entre o que seriam um Direito Constitucional Processual - o conjunto de normas constitucionais que estruturam o Direito Processual - e um Direito Processual Constitucional - processo através do qual a jurisdição constitucional é exercida. ${ }^{14}$

O Direito Constitucional Processual seria formado a partir dos princípios basilares do devido processo e do acesso à justiça, e se desenvolveria através de princípios constitucionais referentes às partes, ao juiz, ao Ministério Público, enfim, os princípios do contraditório, da ampla defesa, da proibição das provas ilícitas, da publicidade, da fundamentação das decisões, do duplo grau, da efetividade, do juiz natural, etc.

Já o Direito Processual Constitucional seria formado a partir de normas processuais de organização da Justiça Constitucional e de instrumentos processuais previstos nas Constituições, afetos à Garantia da Constituição e à Garantia dos direitos fundamentais, controle de constitucionalidade, solução de conflitos entre os órgãos de cúpula do Estado, resolução de conflitos federativos e regionais, julgamento de agentes políticos, recurso constitucional, Habeas Corpus, Amparo, Mandado de Segurança, Habeas Data, etc.

Essa distinção é problemática à luz de uma teoria constitucional constitucionalmente adequada do Direito brasileiro, pelo menos, pelas seguintes razões:

14 Por exemplo, a obra especializada, NERY JÚNIOR, Nelson. Princípios do processo civil na Constituição Federal. São Paulo: Revista dos Tribunais, 1999, p. 20-22. 
1ํ) Por um lado, se o Direito Constitucional é o fundamento de validade de todo o ordenamento jurídico, posto que estabelece os processos através dos quais todas as demais normas serão produzidas, quer da perspectiva legislativa, quer da perspectiva da aplicação jurisdicional, não há Direito Processual que não deva ser, nesse sentido, constitucional. ${ }^{15}$

$2^{\circ}$ ) Por outro lado, no Brasil, apesar de vozes discordantes, ${ }^{16}$ o controle jurisdicional de constitucionalidade das leis e dos atos normativos é fundamentalmente difuso e incidental, como exigência constitucional basilar no esteio da melhor tradição democrática e constitucional brasileira. ${ }^{17}$

Assim, no Brasil e cada vez mais em toda parte, a Constituição estabelece um verdadeiro Modelo Constitucional do Processo (ANDOLINA-VIGNERA), ${ }^{18}$ estruturante do Direito Processual que não pode ser desconsiderado sob pena de inconstitucionalidade e até mesmo de descaracterização do instituto do processo enquanto tal. ${ }^{19}$

No Brasil, nosso controle de constitucionalidade pode dar-se como preliminar de mérito em qualquer processo, cível ou penal, de tal forma que todo cidadão tem o direito de se opor ou de argüir uma inconstitucionalidade e todo juiz ou tribunal, da primeira à última instância, não só pode mas deve, como atividade típica e função intrínseca à jurisdição brasileira, apreciar a constitucionalidade de lei ou ato normativo de qualquer espécie, negando a aplicação de comando eivado de inconstitucionalidade. Nesse sentido é que JOSÉ LUIZ QUADROS DE MAGALHÃES firma: "No Brasil, toda jurisdição é jurisdição constitucional."

Não estamos em WEIMAR. A Ação Direta de Inconstitucionalidade, o Mandado de Segurança, o Habeas Corpus, o Mandado de Injunção nada mais são do que meios processuais especiais, complementares, e, como tais, devem ser compreendidos como formas de concretização do mais amplo modelo do direito à tutela jurisdicional. A atividade jurisdicional que se desenvolve através deles não cria um estado de exceção e nem mesmo o Supremo Tribunal Federal deve assumir o papel de uma corte constitucional kelseniana ou de um presidente do Reich schmitiano. A cidadania não precisa de tutores.

Portanto, não se pode levar tão a sério a distinção entre um Direito Constitucional Processual e um Direito Processual Constitucional a ponto de se chegar a distinguir o que deve estar intimamente relaciona-

15 Sobre isso, ver LEAL, Rosemiro Pereira. Teoria geral do processo. Porto Alegre: Síntese, 1999, p. 61-62.

16 MENDES, Gilmar Ferreira. "O controle incidental de normas no Direito brasileiro". In Revista dos Tribunais, a. 88, v. 760. São Paulo, fev./1999, p. 12.

17 Por exemplo, BARBOSA, Ruy. A Constituição e os actos inconstitucionais do Congresso e do Executivo ante a Justiça Federal. Rio de Janeiro: Atlântida, s.d. Também MAGALHÃES, José Luiz Quadros de. "Reforma do judiciário". In Jornal da Pós-Graduação em Direito da Faculdade de Direito/UFMG, a. 2, n. 12. Belo Horizonte, maio/2000, p. 2-4.

18 ANDOLINA, Italo e VIGNRA, Giuseppe. II modelo costituzionale del processo civile italiano. Torino: Giappichelli, 1990.

19 LEAL, Rosemiro Pereira. Teoria geral do processo. Porto Alegre: Síntese, 1999,p. 61. 
do, Processo e Constituição. Ainda que se admita a existência de um Processo Constitucional, enquanto disciplina a congregar o estudo de instrumentos especiais e complementares de garantia, no Brasil, qualquer processo é constitucional, quer em razão de sua estrutura e de seus fundamentos, quer pelo fato de garantir as condições institucionais para a problematização e para a resolução de questões constitucionais subjacentes às situações concretas de aplicação do Direito Penal, Civil, Comercial, Administrativo, Tributário, etc.

É preciso pontuar, a distinção entre Direito Constitucional Processual e Direito Processual Constitucional possui uma história. Ela surge no contexto histórico de criação de uma jurisdição constitucional concentrada.

No Direito tradicional continental europeu, o juiz comum, assim como o cidadão, deve presumir a constitucionalidade dos atos normativos e das leis e guiar-se pelo entendimento da Corte Constitucional. Em termos kelsenianos, o legislativo e a Corte são autorizados a interpretar a Constituição, o cidadão e o juiz comum não. Questões sobre constitucionalidade ou inconstitucionalidade não devem ser explicitamente tratadas através dos processos comuns e nenhum cidadão pode argüi-las (pelo menos no modelo clássico) e nenhum juiz ordinário pode pronunciar-se acerca delas. Como diria PETER HÄBERLE, trata-se de uma sociedade fechada de intérpretes da constituição. Uma sociedade fechada que criou a doutrina das normas constitucionais programáticas, dos direitos fundamentais em sentido objetivo, que equiparou os direitos a bens negociáveis, que inspirou a doutrina dos escopos metajurídicos do processo, que criou a jurisprudência dos valores.

No Brasil, como nos Estados Unidos, o quadro é outro. Todo cidadão é intérprete da Constituição, qualquer cidadão tem o direito de desobedecer a comandos estatais inconstitucionais e qualquer juiz deve pronunciar-se sobre a inconstitucionalidade desses comandos. Não é sem motivo o fato de que para nós, assim como para os norteamericanos, a decisão judicial é declaratória e com efeitos retroativos; a decisão é o resultado do reconhecimento institucional de um direito concreto a desobedecer. Quem desobedece a uma lei por considerá-la inconstitucional não é criminoso; tem razões públicas para isso. ${ }^{20}$

Passemos, agora, à segunda digressão.

Digressão 2: Argumentação jurídica e tutela jurisdicional dos direitos fundamentais

É notória a classificação histórica dos direitos fundamentais em os de primeira geração (individuais), segunda (sociais), terceira (coletivos) ou até mesmo quarta geração (difusos), ainda que admitida, entre os autores, com alguma modificação. Assim, PAULO BONAVIDES, seguindo KAREL VASAK, vale-se da famosa divisa da Revolução Francesa para também utilizar as expressões direitos de liberdade (primeira geração), direitos de igualdade (segun-

20 CATTONI DE OLIVEIRA, Marcelo Andrade. Devido processo legislativo. Belo Horizonte: Mandamentos, 2000. 
da geração) e direitos de fraternidade ou de solidariedade (terceira geração). E a essas três gerações, sucessivas e cumulativas, acrescenta uma quarta, como sendo o cume de um processo histórico de universalização concreta dos direitos fundamentais, e que assumiria as gerações anteriores como dimensões suas, a geração dos direitos materializados à democracia, à informação e ao pluralismo. ${ }^{21}$ Essa última afirmação possui, com certeza, uma preocupação política e sociológica, ultrapassando a perspectiva meramente cronológica, posto que já assume a noção de interdependência entre os direitos fundamentais, no que se refere ao seu exercício efetivo e concreto.

Como classificação histórica, é discutível o quanto pode contribuir do ponto de vista sistemático da aplicação adequada dos dispositivos que consagram esses direitos, nas chamadas situações de concorrência ou de colisão, principalmente quando se trata de direitos considerados como de gerações diferentes. Isso porque a análise histórica, que procura explicitar os contextos sociais subjacentes à prática jurídica, necessitaria traduzir-se teoreticamente a fim de garantir algum suporte à dogmática jurídica.

A perspectiva teórico-jurídica busca tratar de forma sistemática e operacional, todavia interna ao Direito, o problema da produção e da aplicação jurídicas, o que levaria a uma diferenciação das questões jurídicas em face do seu ambiente social. Em outros termos, não bastaria aos níveis operacionais da produção e da aplicação do Direito uma análise da realidade histórica que reduzisse as decisões jurídicas do presente a uma vinculação estrita com as decisões tomadas no passado, posto que o Direito não poderia ser visto tão-somente como uma questão de fato ou de convenção explícita, como diria RONALD DWORKIN; ${ }^{22}$ quer do ponto de vista de uma produção legislativa politicamente consistente, quer do ponto de vista jurisdicional em que cada caso é um caso. A manutenção da coerência interna ou da integridade do Direito pressuporia uma justificação que ultrapassa no presente as razões concretas articuladas no passado a cada nova decisão.

Todavia, podem ainda permanecer os riscos de se cair na velha armadilha metodológica que idealmente separa ser e dever ser, tanto no que se refere à efetividade do Direito, quanto à eficácia prática da teoria jurídica desenvolvida a cada nova decisão. Corre-se o risco de se idealizar, por um lado, a realidade histórica como algo dado e intransponível ou, por outro, uma capacidade sobre-humana dos operadores jurídicos.

Do ponto de vista metodológico, a tensão entre as análises histórica e teórica, entre a perspectiva empírica de um historiador/observador e a perspectiva normativa de um operador teórico-pragmático que garantiria no máximo uma metodologia sem métodos, pode ter reduzida a sua complexidade através da noção de paradigma jurídico. 
O uso da noção de paradigma jurídico pretende estabilizar a tensão entre realidade e idealidade, ao defender a tese de que haveria um horizonte histórico de sentido, ainda que mutável, para a prática jurídica concreta, que pressuporia uma determinada percepção do contexto social do Direito, a fim de se compreender em que perspectiva as questões jurídicas deveriam ser interpretadas para que o Direito possa cumprir seu papel nos processos de integração social. Assim, a cada nova geração, o certo seria que os direitos não são simplesmente alargados, mas sim redefinidos a cada novo paradigma.

No que se refere especificamente à aplicação jurídica, uma reconstrução paradigmática do Direito combinaria história e teoria, procurando retirar dos ombros do operador jurídico um papel ou encargo que só poderia ser desempenhado por um juiz Hércules: uma vez reconstruído o paradigma, ter-se-ia, sem maiores mediações, um vetor interpretativo para a resolução de questões jurídicas.

Nesse sentido, para MENELICK DE CARVALHO NETTO, ${ }^{23}$ ao se falar em geração de direitos não se poderia tão-somente considerar uma sucessiva cumulação de direitos ou até mesmo um progressivo alargamento da efetividade do exercício dos direitos de uma geração passada pelos direi- tos da geração seguinte: seria necessário reconhecer que tal cumulação implica inclusive uma redefinição paradigmática dos velhos em novos direitos.

\section{Para JOSÉ LUIZ QUADROS DE} MAGALHÃES, principalmente após a obra Poder Municipal, ${ }^{24}$ que de certa forma altera o enfoque anteriormente dado à questão em Direitos Humanos na Ordem Jurídica Inter$n a,{ }^{25}$ a chamada teoria da interdependência dos direitos humanos já apontaria nesse sentido. O reconhecimento da interdependência entre os direitos romperia com o enfoque histórico-cronológico que marca a classificação dos direitos em gerações, posto que o sentido da validade jurídica, da vigência e da efetividade dos direitos que comporiam o chamado núcleo indivisível fundamental deveria resultar modificado em razão de uma nova compreensão jurídica, a cada nova ruptura paradigmática. $\mathrm{Ou}$ seja, a cada novo paradigma haveria a necessidade de se redefinir como compatibilizar o sentido de um direito em relação aos dos outros, e vice-versa. Para tanto, caberia lançar mão de noções tais como ideologia constitucionalmente adotada, economicidade ou linha de maior vantagem, ${ }^{26}$ algo que, sem dúvida, pressupõe uma visão paradigmática típica do Estado de Bem-Estar Social, ainda que pouco explicitada, do que seja aplicar o Direito.

23 CARVALHO NETTO, Menelick de. "Requisitos pragmáticos da interpretação jurídica sob o paradigma do Estado Democrático de Direito". In Revista de Direito Comparado. Mandamentos e Pós-Graduação da Faculdade de Direito/UFMG, v. 3. Belo Horizonte, 1998, p. 480-481.

24 MAGALHÃES, José Luiz Quadros de. Poder municipal. Belo Horizonte: Del Rey, 1997.

25 MAGALHÃES, José Luiz Quadros de. Direitos humanos na ordem jurídica interna. Belo Horizonte: Interlivros, 1992.

26 SOUZA, Washington Albino Peluso de. "Conflitos ideológicos na constituição econômica". In Revista Brasileira de Estudos Políticos/UFMG, v. 74-75. Belo Horizonte, jan.-jul./1992, p. 35. 
Também, em sentido semelhante, ANTONIO AUGUSTO CANÇADO TRINDADE 27 é enfático ao afirmar que a classificação dos direitos em gerações é "uma fantasia desagregadora, historicamente incorreta e juridicamente infundada". Uma aplicação adequada das normas jurídicas internacionais (e nacionais) deve partir de uma "visão holística dos direitos humanos, da inter-relação e integralidade necessária de todos os direitos humanos", que se conseguiria guiando-se pelos "valores comuns superiores que abrigam e em que se inspiram". Deslocando-se cada vez mais do terreno da política para o do Direito, esse autor considera que não se trataria somente de justificar a efetividade interdependente entre os direitos no plano sociológico e político da sua promoção, mas também na perspectiva da sua proteção jurisdicional.

Todavia, a tentativa de se reduzir a complexidade da interpretação jurídica através da reconstrução de um paradigma jurídico concreto (ou, ainda, da determinação não isenta de problemas de uma ideologia constitucionalmente adotada ou de um quadro de valores comuns superiores), que desde o início já estabeleceria um horizonte histórico de sentido para a prática jurídica, só retiraria em parte dos ombros do juiz a tarefa hercúlia de pôr em relação os traços relevantes de uma situação concreta, apreendida de forma a mais complexa possível, com todo um conjunto de normas em princípio aplicáveis, pois o reconhecimento de que há paradigmas jurídicos que informam e conformam a prática jurídica leva hoje a uma disputa não só jurídica mas política acerca de qual dentre eles é o adequado à compreensão do Direito, no contexto histórico percebido de uma sociedade aberta de intérpretes, a cada situação concreta.

Segundo HABERMAS, ${ }^{28}$ a interpretação jurídica se dá hoje no contexto de uma disputa entre distintas compreensões paradigmáticas do Direito, que se tornaram reflexivas. A naturalização de certezas, própria de todo paradigma, pode ser vista, no contexto de um pluralismo social, político e cultural, como pura ideologia, posto que "a interpretação coerente de um caso no marco de um paradigma jurídico fixo permanece essencialmente infradeterminada; tal interpretação terá de competir com outras interpretações também coerentes do caso em paradigmas jurídicos alternativos". 29

Com a crise do paradigma de bemestar social e mesmo com as tentativas empreendidas pela dogmática jurídica de escapar da alternativa paradigma liberal ou paradigma social, inclusive procurando estabelecer conexões mais ou menos híbridas entre eles, fomentou-se uma compreensão reflexiva do Direito, assim como a necessidade de se problematizar modelos sociais que estariam inscritos no próprio Direito.

27 CANÇADO TRINDADE, Antonio Augusto. "Memorial em prol de uma nova mentalidade quanto à proteção dos direitos humanos nos planos internacional e nacional". In Revista de Direito Comparado. Mandamentos e Curso de Pós-Graduação da Faculdade de Direito/UFMG, v. 3. Belo Horizonte, 1998, p. 57.

28 HABERMAS, Jürgen. Facticidad y validez. Trad. Jiménez Redondo. Madri: Trotta, 1998, p. ex., p. 293 e p. 477.

29 HABERMAS, Jürgen. Facticidad y validez. Trad. Jiménez Redondo. Madri: Trotta, 1998, p. 293. 
Na prática jurídica do cotidiano dos operadores jurídicos, e que em muito ultrapassa o círculo fechado dos especialistas, os paradigmas jurídicos permanecem em tensão, concorrendo caso a caso para a interpretação do suposto Direito aplicável.

Essa tensão é que se pretende justamente mascarar, quando a teoria constitucional do bem-estar social fala em colisão ou em concorrência de direitos, e pretensiosamente busca resolvê-las à base de uma negociação/otimização de bens juridicamente protegidos.

\section{Segundo GOMES CANOTILHO, ${ }^{30}$} ocorreria uma concorrência de direitos quando um comportamento do mesmo titular preenchesse os pressupostos de fato de vários direitos (cruzamento) ou quando determinado bem jurídico levasse à acumulação, na mesma pessoa, de vários direitos, o que levaria à discussão acerca de qual direito é mais ou é menos limitado, com o fim de se determinar qual assumiria relevo decisivo. Ocorreria uma colisão de direitos quando o exercício de um direito por seu titular colidisse ou conflitasse com o exercício do direito por outro titular, o que levaria a uma discussão acerca de quais direitos admitiriam restrições e quais não, através de um juízo de ponderação e de valoração de prevalência. ${ }^{31}$

Em sua crítica a essa compreensão, típica de uma jurisprudência de valores, tan- to HABERMAS quanto GÜNTHER alertam para os riscos de se confundir princípios normativos com valores otimizáveis e direitos com bens negociáveis, uma compreensão metodológica errônea em face do caráter deontológico do Direito. As normas jurídicas e os direitos nelas previstos estabelecem uma relação de obrigatoriedade e não de preferência ou atratividade. ${ }^{32}$

No paradigma do Estado Democrático de Direito, o discurso liberal e o discurso de bem-estar devem ser considerados reflexiva e criticamente como razões ou até mesmo lógicas argumentativas concorrentes, em face de cada situação concreta de aplicação.

Essa afirmação pretende justificar uma compreensão procedimentalista do Direito a qual "assinala o nível ou o plano em que os paradigmas jurídicos, convertidos em reflexivos, se abrem uns aos outros e podem ter crédito na diversidade, mobilizada em cada caso, que representam as distintas interpretações possíveis da situação". ${ }^{33}$

Isso é de uma aplicabilidade prática considerável, por exemplo, no uso dos meios processuais de proteção dos direitos fundamentais.

A distinção entre direitos individuais, coletivos, sociais e difusos é uma distinção lógico-argumentativa. Deve ser

30 GOMES CANOTILHO, José Joaquim. Direito constitucional e teoria da constituição. Coimbra: Almedina, 1998, p. 1135 e ss.

31 ALEXY, Robert. Teoría de los derechos fundamentales. Trad. Garzón Valdés. Madri: Centro de Estudios Constitucionales, 1993.

32 HABERMAS, Jürgen. Facticidad y validez. Trad. Jiménez Redondo. Madri: Trotta, 1998, p. 326 e ss; GÜNTHER, Klaus. The sense of appropriateness. Trad. John Farrell, Nova York: State University of New York Press, 1993, p. 240-241.

HABERMAS, Jürgen. Facticidad y validez. Trad. Jiménez Redondo. Madri: Trotta, 1998, p. 293. 
considerada do ponto de vista do processo argumentativo de aplicação das normas que lhes consagram. Assim, é possível a utilização dos mais variados meios processuais, quer individuais, quer coletivos, para a tutela jurisdicional desses direitos.

Essa perspectiva é mais radical do que aquela fundada na chamada interdependência dos direitos, que comporiam o núcleo fundamental e indivisível dos direitos humanos. Isso, porque, aqui, não se trata simplesmente de uma aplicação ponderada, proporcional ou compromissória de normas constitucionais, semanticamente consideradas, que pretende restringir ou otimizar o exercício dos direitos.

Uma argumentação jurídica de aplicação ponderada, proporcional ou ótima de dispositivos normativos, guiada por uma compreensão axiológica do Direito, confunde e reduz a aplicabilidade ou adequabilidade de uma norma à justificação ou extensão da sua validade ou vigência jurídicas. Nos discursos de aplicação, não se pretende apresentar argumentos pragmáticos, éticos ou morais que venham a justificar a extensão em grau ótimo da validade/ legitimidade ou do âmbito jurídicos de uma norma, mas a sua adequabilidade procedimentalmente justificada a cada caso concreto, livre de qualquer predeterminação material em que se dê prioridade a certos pontos de vista normativos sobre outros. ${ }^{34}$

Estaremos, portanto, tratando do processo de aplicação adequada de normas jurídicas, argumentativamente fundada nos termos do caso concreto, à luz de paradigmas jurídicos concorrentes, liberal e de bem-estar que, por serem concorrentes e nada absolutos, cobram reflexividade, abertura e crítica, no quadro de uma compreensão procedimentalista do Direito. Assim, o Direito não pode ser reduzido quer a uma lógica argumentativa referente a programas condicionais (a regras), quer a programas finalistas (a políticas), como forma privilegiada de regulação.

Conseqüência disso é que não se pode fixar em definitivo (modelo de regras) o que apenas é disposto prima facie (modelo de princípios). Se partirmos de uma concepção procedimentalista do Direito, em que qualquer proposição jurídica é fruto de interpretação, sobre o pano de fundo de visões paradigmáticas concorrentes, não se pode pré-definir o conteúdo ou a extensão total de um dispositivo normativo, que ganha sentido a cada novo caso concreto, predeterminando-se materialmente a argumentação. É necessário, mais uma vez, romper com uma teoria material do Direito e dos direitos que estabelece um modelo padrão, fixo, para a sua efetivação, até mesmo porque a dinâmica de uma sociedade democrática e pluralista não coaduna com visões privilegiadas e excessivamente concretas do que seja vida, liberdade, igualdade, segurança, trabalho ou até mesmo dignidade humana.

$\bigcirc$ direito à liberdade de expressão, por exemplo, num caso concreto, pode ser considerado, conforme argumentação adequada,

34 GÜNTHER, Klaus. The sense of appropriateness. Trad. John Farrell. Nova York: State University of New York Press, 1993, p. 240. 
empreendida pelas partes e devidamente apreciada pelo juiz, como direito individual, coletivo, social e até mesmo difuso, a legitimar, quer o meio processual individual, quer o coletivo, para a sua tutela jurisdicional. Daí se poder protegê-lo quando se tolhe ou se ameaça tolher a palavra de alguém; ou a participação de uma associação representativa de uma coletividade; quando se afirma que a educação é pressuposto do ter o que dizer; ou quando se discute o impacto na comunidade da violência, da pornografia na televisão ou na Internet; ou ainda a existência ou não de monopólio dos meios de comunicação.

Não é sem razão que uma das maiores vantagens do nosso sistema de garantias processuais é que o meio coletivo não deve excluir a priori o individual, e viceversa, como se pode adequadamente compreender as disposições, por exemplo, da Lei da Ação Civil Pública (art. 1ํㅡㄹ da Lei Federal no 7.347/85), combinando-as com as do Código de Defesa do Consumidor (arts. 81, $83,91,94,97,98,103, \S 3^{\circ}$, e 104 da Lei Federal no 8.078/90).

Cabe considerar que a inter-relação entre esses diplomas normativos, explicitamente prevista pela Lei Federal no ${ }^{\text {o }}$.078/ 90, que determina aplicar seus dispositivos à ação civil pública (art. 117) e aplicar os dispositivos da Lei Federal nº 7.347/85 às ações que prevê (art. 90), cria um verdadeiro código de ações coletivas ${ }^{35}$ que viabilizam a tutela jurisdicional dos chama- dos direitos trans ou metaindividuais, em que direitos individuais homogêneos, direitos coletivos e direitos difusos não são estabelecidos num catálogo fechado (novo art. 1ํ, IV, da Lei da Ação Civil Pública e art. 81, parágrafo único, I, II e III, do Código de Defesa do Consumidor).

Por um lado, o que sejam direitos individuais homogêneos, direitos coletivos e direitos difusos, com base no art. 81, parágrafo único, incisos I, II e III, do Código de Defesa do Consumidor, só pode ser determinado e até mesmo diferenciado através de uma argumentação jurídica de aplicação adequada em cada processo jurisdicional, tendo-se em vista o caso concreto.

Por outro, não há uma excessiva confiança, nem no meio processual coletivo e nem nos legitimados processualmente para o seu uso, ${ }^{36}$ o que pode ser esclarecido através de uma interpretação adequada dos dispositivos normativos que determinam os legitimados (que são partes legais) para propor essas ações, podendo ser eles instâncias políticas (União, Estados, Municípios), administrativas (órgãos e agências públicas especializadas ou não), o Ministério Público ou associações da sociedade civil (em que a necessidade de pré-constituição e de previsão estatutária podem ser afastadas); a que título se legitimam (representação e não substituição processual); e de que forma as decisões, favoráveis ou desfavoráveis (por ausência de provas ou não) os atingem, enquanto partes (legais) que são para propor as

35 MARINONI, Luiz Guilherme. Novas linhas de processo civil. São Paulo: Malheiros, 2000.

36 GONÇALVES, Aroldo Plínio. "A coisa julgada no Código de Defesa do Consumidor e o novo conceito de parte". In Revista Forense, separata do v. 331. Rio de Janeiro, 1995. 
ações e não como titulares dos direitos que se pretende tutelar jurisdicionalmente (arts. 82, 91, 94, 103 e 104 do Código de Defesa do Consumidor).

Conforme o caso, por exemplo, o direito ao meio ambiente saudável pode ser tratado argumentativamente como questão interindividual de direito de vizinhança, como condições adequadas de trabalho de uma categoria profissional, ou até mesmo como direito das gerações futuras: depende da perspectiva argumentativa, se individual, coletiva, social ou difusa de quem o defender.

Devemos abandonar teorias semânticas da interpretação ${ }^{37}$ que pretendem fixar abstratamente e fora do contexto de aplicação a extensão do sentido dos textos normativos. Isso implica não somente abandonar uma teoria material do Direito, como também uma teoria estrutural das normas jurídicas que pretende fixar a interpretação adequada dos textos normativos à base da sua literalidade.

Modelos interpretativos são sempre bem vindos, como verdadeiros redutores da complexidade interpretativa, ainda que passíveis de abertura e de revisão. Mas dizer, por exemplo, que o Ministério Público não poderá defender direitos a não ser os coletivos e difusos, nunca os individuais homogêneos, que os direitos coletivos e difusos são tais ou quais, previstos nos artigos tais, fixados numa lista fechada ou só defensáveis em única perspectiva, é reduzir as possibilidades de acesso à jurisdição e negar, de antemão, a tutela jurisdicional, através de meio processual que poderá ser o coletivo, cuja adequação só poderá ser analisada caso a caso.

Um direito é individual, coletivo, social ou difuso conforme seja definido, através da argumentação jurídica adequada, caso a caso: é correto afirmar, por exemplo, que uma associação de pescadores pode defender o meio ambiente marítimo, numa situação concreta, porque seus associados ou até mesmo toda uma coletividade retira o seu sustento da pesca legalmente permitida, ainda que tal finalidade ambientalista não esteja prevista em seus estatutos. Não há pesca de peixe morto, contaminado ou ameaçado de extinção.

Poder-se-ia considerar ameaçadas a certeza e a segurança jurídicas com o raciocínio jurídico que expomos. Mas o que é certeza jurídica hoje? A certeza ou previsibilidade do conteúdo das decisões, como se o Direito pudesse ser mecanicamente aplicado?

Se exceto algumas enunciados normativos cujas cláusulas especificam em tal nível de detalhe as condições de aplicação que só se podem aplicar a poucas situaçõespadrão altamente tipificadas e bem circunscritas (as regras, para usar um conceito de RONALD DWORKIN), todas as normas válidas são, de início, indeterminadas em sua referência e têm necessidade de conexões relacionais adicionais no caso concreto individual, via argumentação - o que vale não só para os princípios e direitos constitucio- 
nais estruturantes do sistema jurídico; se elas são aplicáveis prima facie, no sentido de que devemos ingressar em um discurso de aplicação para comprovar se encontrarão aplicação em uma situação não prevista pelo processo de justificação ou se, embora válidas, devem ceder a outras, essas, sim, adequadas; se uma norma somente fundamenta um juízo normativo singular, que pode ter a pretensão de ser correto, se essa norma se comprovar singularmente adequada ao caso em questão; se a validade prima facie de uma norma tão-somente significa que essa norma foi imparcialmente justificada; e se a solução correta advém, pois, do desenvolvimento de um senso de adequabilidade normativa, de uma interpretação racional e argumentativamente fundada em cada situação, tendo-se em vista reconstruções paradigmáticas apropriadas do Direito vigente, ${ }^{38}$ a resposta à questão acerca de uma certeza jurídica que poderia ser alcançada, não importa a argumentação jurídica que se realize, só pode ser não.

Deveríamos, então, renunciar à nossa pretensão cotidiana de certeza e de segurança em prol de um uso alternativo (ou nenhum uso!) do Direito, pragmaticamente considerando que a legitimidade das decisões só poderia ser alcançada a posteriori, tendo-se em vista o seu impacto político, econômico, ético ou social, como quer o Realismo Jurídico, ontem e hoje? Também não.
Numa sociedade lingüisticamente estruturada, plural e sem a possibilidade de fundamentos absolutos, a única certeza pela qual podemos lutar é a de que os melhores argumentos, em uma situação de participação em simétrica paridade entre as partes que serão afetadas pelo provimento jurisdicional, sejam levados corretamente em consideração, ao longo do processo e no momento da decisão, por um juiz que demonstre a sua imparcialidade. ${ }^{39}$

Aqui, a questão metodológica entrecruza-se, mais uma vez, com o problema da legitimidade das decisões.

Há muito a questão acerca da legitimidade das decisões judiciais deixou de ser um problema que se reduza tão-somente à pessoa do juiz, sua virtude ou sua forma de seleção, ou a um momento quase mítico de tomada de decisão. $\bigcirc$ que garante a legitimidade das decisões são antes direitos e garantias fundamentais, de caráter processual, atribuídas às partes e que são, principalmente, os do contraditório e da ampla defesa, além da necessidade racional de fundamentação das decisões. Embora o Direito diga respeito a todos os cidadãos, nos discursos de aplicação essa necessidade de legitimidade afeta diretamente aqueles que sofrerão os efeitos do provimento jurisdicional. ${ }^{40}$

Assim, como se trata de um processo argumentativo, a construção da decisão

38 GÜNTHER, Klaus. "Uma concepção normativa de coerência para uma teoria discursiva da argumentação jurídica". Trad. Leonel Cesarino Pessôa. In Cadernos de Filosofia Alemã, n. 6. São Paulo, 2000, p. 85-102.

39 HABERMAS, Jürgen. Facticidad y validez. Trad. Jeménez Redondo. Madri: Trotta, 1998; GONÇALVES, Aroldo Plínio. Técnica processual e teoria do processo. Rio de Janeiro: Aide, 1992.

40 HABERMAS, Jürgen. Facticidad y validez. Trad. Jeménez Redondo. Madri: Trotta, 1998; GONÇALVES, Aroldo Plínio. Técnica processual e teoria do processo. Rio de Janeiro: Aide, 1992. 
judicial, que importa na determinação da norma adequada a um dado caso, assegurada num nível institucional, depende do entrelaçamento de argumentos e de perspectivas de interpretação acerca do caso concreto que não pode, por um lado, deixar de considerar os pontos de vista dos diretamente implicados, nem, por outro, se deixar reduzir à sua mera consideração. $\bigcirc$ que se coloca em questão, nesse momento, é a própria garantia de integridade do Direito, a fim de se garantir tanto a coerência normativa da decisão ao sistema jurídico, quanto a sua adequabilidade ao caso concreto.

Toda essa digressão leva, pelo menos, à necessidade de se ultrapassar as noções de devido processo formal e de devido processo material, no que se refere à dimensão institucional da argumentação jurídica de aplicação. Essa articula-se com o Direito Processual, impossibilitando que seja tratada como um caso especial de argumentação moral, mas todavia garantindo no aspecto temporal, social e objetivo que ela ganhe curso, sem que haja uma prédefinição formal ou material a algum fim que se possa pretender alcançar, a não ser o da construção imparcial, coerente e participada da decisão: tal seria, inclusive, a noção que consideramos a atual do princípio constitucional do devido processo legal.

Uma vez que explicitada a dimensão operacional de uma teoria do Direito constitucionalmente adequada ao paradigma do Estado Democrático de Direito, retomaremos, agora, a tarefa de reinterpretação da jurisdição constitucional brasileira.

\section{Jurisdição constitucional brasileira}

Como reconstruir adequadamente, pois, o papel da jurisdição constitucional, jurisdição em matéria constitucional, no Brasil?

Partindo de uma compreensão da Constituição, sob o paradigma do Estado Democrático de Direito, como a regulação de processos que visam a garantir o exercício da autonomia jurídica, numa perspectiva que supera tanto o paradigma liberal, quanto o paradigma de bem-estar social, de Constituição e de autonomia, poderemos reconstruir a tarefa da jurisdição constitucional como primordialmente referida ao exame e à garantia de realização das condições procedimentais, das formas comunicativas e negociais, para um exercício discursivo da autonomia política. Os direitos fundamentais exprimem essas condições, possibilitam um consenso racional, ou, ao menos, um processo equânime de negociação, acerca da institucionalização das normas do agir, e tornam possível a gênese democrática do Direito. Através da participação discursiva no processo legislativo democrático, os destinatários das normas jurídicas são os autores das mesmas. Tal referência às condições procedimentais do processo legislativo democrático não faz da jurisdição constitucional um poder legislativo, ainda que negativo, nem tão pouco a tornará um guardião republicano de um processo político restrito a questões éticoculturais, como numa leitura republicana do paradigma do Estado Social.

Procuraremos, agora, delinear, em termos analíticos, como deve ser compreendido 
o papel da jurisdição constitucional no controle jurisdicional de constitucionalidade das leis e do processo legislativo, no marco da Constituição da República brasileira, sob o Estado Democrático de Direito. Buscaremos caracterizar, em linhas gerais, o controle jurisdicional de constitucionalidade das leis e do processo legislativo, em via principal e em via incidental, como atividade de aplicação jurídico-normativa.

A tarefa geral da jurisdição constitucional e, especialmente, no controle jurisdicional de constitucionalidade das leis e do processo legislativo, no marco da Constituição da República brasileira, sob paradigma do Estado Democrático de Direito, é a de garantia das condições processuais para o exercício da autonomia pública e da autonomia privada dos co-associados jurídicos, no sentido da interdependência e da equiprimordialidade delas. Essa tarefa densifica-se nas seguintes perspectivas:

\section{Garantia do devido processo} legislativo democrático; ou seja, democracia e abertura nos discursos legislativos de justificação das normas jurídicas do agir. Sob o paradigma do Estado Democrático de Direito, a jurisdição constitucional deve referir-se primeiramente aos pressupostos comunicativos e às condições processuais para uma gênese democrática do Direito. Tal perspectiva não poderá reduzir-se a uma leitura meramente instrumental do processo legislativo, como sugerem os enfoques liberais da política, pois há que se levar explicitamente em conta o caráter normativo dos princípios constitucionais que justificam a legitimidade desse processo. Mas esses princípios não podem nem necessitam ser interpretados como valores concretos de uma dada tradição ético-política, como sugerem alguns republicanos, a partir de uma teoria substantiva dos direitos fundamentais ou de uma teoria do devido processo substantivo.

2. Garantia do devido processo constitucional; ou seja, imparcialidade e adequabilidade nos discursos de aplicação jurídica em geral. Nessa perspectiva, a jurisdição constitucional deve garantir, de forma constitucionalmente adequada, a participação ou a representação nos processos ordinários cíveis, penais e nos processos especiais de garantia de direitos constitucionais e de controle jurisdicional de constitucionalidade, dos possíveis afetados por cada decisão, através de uma interpretação construtiva que compreenda o próprio processo jurisdicional como garantia das condições para o exercício da autonomia jurídica dos cidadãos. Ao possibilitar a garantia dos direitos fundamentais processuais jurisdicionais, nos próprios processos de controle jurisdicional de constitucionalidade, em via incidental ou principal, a jurisdição em matéria constitucional também garantirá as condições para o exercício da autonomia jurídica dos cidadãos, pela aplicação a si mesma do princípio do devido processo legal, compreendido, aqui, como modelo constitucional do processo.

Desse modo é que a garantia dos direitos fundamentais, da autonomia política, capacidade para uma escolha racional e auto-realização ética - que se ramifica no uso público das liberdades comunicativas e no uso privado das liberdades subjetivas - e a garantia do direito das gerações futuras ao exercício da autonomia jurídica repousam 
e são desenvolvimentos das duas garantias constitucionais processuais básicas acima elencadas.

Como a atuação da jurisdição constitucional deve referir-se às condições procedimentais do processo legislativo constitucionalmente estruturado, de acordo com o qual os cidadãos, no exercício de seu direito de autodeterminação, possam realizar o projeto cooperativo de estabelecer condições recorrentemente mais justas de vida, essa atuação deve justamente assegurar o sistema de direitos que apresentam tais condições procedimentais e que, assim, garantem as autonomias pública e privada dos cidadãos, não somente perante o poder administrativo do Estado mas também em face do poder social e econômico.

Vista da perspectiva da garantia do direito das gerações futuras ao exercício da autonomia jurídica, a tarefa da jurisdição em matéria constitucional envolve a própria questão acerca do futuro da democracia entre nós, assim como a relação entre a Constituição e o tempo, o que envolve a reconstrução, por exemplo, de um princípio constitucional da reversibilidade dos entendimentos jurisprudenciais subjacentes das decisões, ao lado de um princípio da não-escravidão voluntária, como corolários do princípio democrático, princípios, esses, que devem estruturar os processos formais e informais de mudança constitucional. Nesse sentido, no que se refere aos processos formais, cabe dizer que a jurisdição constitucional, no exercício do controle jurisdicional de constitucionalidade do processo legislativo de reforma constitucional, deve garantir as condições procedimentais de um processo democrático de reforma, no tempo, das interpretações subjacentes às decisões políticas e jurídicas fundamentais, acerca de o que deva ser ojuridicamente correto, possibilitando às gerações futuras a apropriação reflexiva das tradições político-constitucionais, no sentido de que a Constituição deverá ser sempre considerada como um projeto em aberto, numa Democracia. Por outro lado, a garantia de um processo legislativo democrático de reforma constitucional deve impedir que os dispositivos constitucionais sejam objeto de alteração através do exercício de um poder constituinte derivado distanciado das fontes de legitimidade situadas nos fóruns de uma esfera pública política que não se reduz ao Estado. $O$ que leva a que mais uma vez se retome, explícita e radicalmente, a pergunta pelos fundamentos democráticos e pluralistas do constitucionalismo, relacionados à própria pretensão de legitimidade do Direito moderno e dos vínculos constitucionais.

Mas isso não pode fazer da jurisdição constitucional, como já assinalado anteriormente, uma guardiã republicana do processo político e da cidadania, que a transformaria numa espécie de poder constituinte permanente.

Uma interpretação do processo político fundada numa compreensão procedimental do Direito e da política não deve conceber a política deliberativa como um processo estabilizador de identidades éticoculturais, nem muito menos reduzir o Direito a uma eticidade consuetudinariamente herdada. A formação democrática da vontade e da opinião, ao contrário do que pressu- 
põe a tradição republicana do pensamento político, não tira sua força legitimadora da convergência de convicções e de razões éticas, mas dos pressupostos comunicativos e dos processos que possibilitam o aporte de razões e interesses de amplo espectro, de tal modo a selecionar os melhores argumentos. A autonomia pública, assim como o Direito, não pode ser assimilada a uma concepção ética, o que fundamenta, segundo HABERMAS, o fato de a Teoria do Discurso não precisar reservar o modo da política deliberativa a condições excepcionais. ${ }^{41}$ Assim, a jurisdição constitucional, com base numa compreensão procedimentalista da Constituição, não tem que buscar sua legitimidade em tais condições excepcionais. Ela pode permanecer no quadro de sua autoridade para aplicar o Direito, na certeza de que o processo democrático, que ela deve proteger, não precisa ser descrito como um estado de exceção. Temos, para isso, de livrar o conceito de política deliberativa de conotações excessivas, impostas por uma concepção republicana do processo político, que colocariam a jurisdição constitucional sob permanente pressão. Concordando com HABERMAS, ela "não pode assumir o papel de um regente que toma o lugar de um sucessor menor de idade ao trono". ${ }^{42}$

No quadro traçado da jurisdição constitucional, será possível compreender o controle jurisdicional de constitucionalidade das leis e do processo legislativo, no Brasil, tanto em via incidental quanto em via principal, como atividades processualmente institucionalizadas de aplicação do Direito: o controle jurisdicional de constitucionalidade não deverá ser exercido da perspectiva de um legislador negativo ou positivo.

controle por via incidental iniciase com vistas à resolução de casos individuais e, por isso, limita-se à aplicação de normas constitucionais, afastando-se do sentido inconstitucional dos dispositivos normativos. Desse modo, sua caracterização como atividade de aplicação do Direito não deve levantar grandes questionamentos em relação à sua natureza. Ao possibilitar a garantia dos direitos fundamentais, reafirma as condições do exercício das autonomias pública e privada pelos cidadãos e, nesse sentido, o controle jurisdicional de constitucionalidade por via incidental também pode ser reconstruído tendo-se por referência a dinâmica do processo de elaboração democrática do Direito.

Já o controle jurisdicional de constitucionalidade por via principal, que tantas questões vem suscitando ao longo dos anos, para ser reconstruído no quadro traçado da jurisdição constitucional democrática, deve diretamente referir-se às condições procedimentais para a realização do processo democrático e das formas deliberativas da formação política da opinião e da vontade. Tais condições, por sua vez, referem-se ao exercício discursivo das autonomia pública que viabiliza o processo

41 Segundo HABERMAS, Direito e democracia: Entre facticidade e validade. Trad. Flávio Beno Siebeneichler. Rio de Janeiro: Tempo Brasileiro, v. I, 1997, p. 345: "A tradição republicana sugere um tal excepcionalismo, uma vez que liga a prática política dos (cidadãos) ao ethos de uma comunidade naturalmente integrada. A política correta só pode ser feita por (cidadãos) virtuosos".

HABERMAS, Jürgen. Direito e democracia: Entre facticidade e validade, vol.I, p. 347. 
legislativo democrático, através do qual os próprios cidadãos são os autores de seus próprios direitos e deveres, na dinâmica da gênese legítima do Direito.

E de que modo se relacionam o controle por via incidental e o controle por via principal? Em princípio, essa questão ganha concretude ao ser respondida no quadro de uma ordem jurídica específica, e que consagra os dois modos de controle. No Direito brasileiro, o controle por via incidental deve ser compreendido como modo ordinário, assim como o controle por via principal deve ser compreendido como modo especial, de controle jurisdicional de constitucionalidade, não somente por razões históricas, jurisprudencialmente assentadas, mas em função da sistemática do controle jurisdicional de constitucionalidade das leis e do processo legislativo, no quadro da Constituição da República. Tal compreensão seria a única que possibilitaria uma visão não-excludente ou nãoincompatível dos dois modos de controle.

As conseqüências de se caracterizar o controle por via incidental como modo ordinário e o controle por via principal como modo especial são, fundamentalmente, as seguintes:

1. a normativa do controle em via incidental se aplica subsidiariamente ao controle em via principal;

2. o controle em via incidental e o controle em via principal são complementares.
Tais afirmações podem ser exemplificadas ao analisarmos os efeitos e a natureza das decisões jurisdicionais tomadas em sede de um e do outro modo de controle. Aqui, pretendemos afastar uma série de malentendidos, à luz de o que viemos considerando uma compreensão da jurisdição constitucional, no marco do Estado Democrático de Direito.

Tradicionalmente, os autores europeus e norte-americanos têm-se dividido ao caracterizar os efeitos e a natureza das decisões jurisdicionais constitucionais. $\mathrm{E}$ isso está bastante relacionado ao modo com que fundamentalmente concebem a jurisdição constitucional, quer como atividade de aplicação do Direito, ainda que construtiva, quer como legislador negativo ou até como legislador positivo, concorrente ou, ao menos, subsidiário.

As posições são, fundamentalmente, três: ${ }^{43}$

1. as decisões têm sempre caráter declaratório, atingindo quer as partes, quer a todos, dependendo de como a questão é suscitada, e sempre em caráter retroativo;

2. as decisões têm sempre caráter constitutivo, atingindo quer as partes, quer a todos, por um lado, podendo, por outro, retroagir ou não, conforme o Direito vigente;

3. o caráter e os efeitos da decisão estão relacionados ao modo de controle, se por via incidental, se por via principal.

43 Acerca de tais posições, ver também BARACHO JÚNIOR, José Alfredo de Oliveira. "Efeitos do pronunciamento judicial de inconstitucionalidade no tempo". In Cadernos da Pós-Graduação (Teoria Geral do Processo Civil), Pós-Graduação em Direito/ UFMG. Belo Horizonte, 1995, p. 25 e ss. 
As duas primeiras posições são as que tentam conciliar, de alguma forma, os dois modos de controle, e, por isso, em princípio, são candidatas em razão do seu caráter sistemático. A terceira, por estabelecer uma relação de concorrência ou até de oposição entre os dois modos de controle, perde em sistemática, mas, ao final, poderá ser descartada em razão de outros argumentos.

A primeira posição é tradicionalmente exposta em termos individualistas, enquanto a segunda, em termos estatalistas. A primeira afirma que a norma inconstitucional é uma contradição em termos e que, portanto, pode ser reconhecida por qualquer um como inválida e nula, no sentido de que ninguém está submetido a um comando inconstitucional. A segunda considera que tão-somente os órgãos estatais competentes e autorizados para tanto podem pronunciar-se a respeito da inconstitucionalidade de uma norma e fazêla cessar de gerar efeitos, ou seja, de anulála. Mesmo a nulidade, para a doutrina que defende a natureza constitutiva da decisão jurisdicional, seria apenas o grau mais alto de anulabilidade, de uma anulação a operar efeitos retroativos. ${ }^{44}$

A teoria que chamaremos estatalista pode ser analisada a partir de uma crítica à sua maior representante, a teoria kelseniana.
Essa seria estatalista porque está fundada, antes de tudo, num positivismo jurídico que, ao contrário do que muitas vezes se afirma acerca da obra kelseniana, está adequada ao paradigma do Estado Social, na medida em que instrumentaliza, através da noção de interpretação autêntica ou autorizada, a discricionariedade necessária ao desenvolvimento de políticas governamentais de impacto, cujo mérito nunca poderia ser conhecido pela Ciência do Direito..$^{45}$ KELSEN restringe, assim, a comunidade de intérpretes autorizados da Constituição aos órgãos jurídicos, não a estendendo a todo o público de cidadãos, o que o leva a não diferenciar aquele que nega a força vinculante do comando por não reconhecer a sua objetividade, ou seja, o seu fundamento de validade, como o mero criminoso, que desobedece à norma sem apresentar razões plausíveis, já que todos os dois assim se comportariam por sua conta e risco. ${ }^{46}$

Ao assim conceber o processo de interpretação e aplicação do Direito, como uma questão de decisão juridicamente institucionalizada, de produção discricionária do Direito, KELSEN inverte a lógica do controle de constitucionalidade, privilegiando, mais que uma pretensão de validade dos comandos estatais, uma compreensão da dinâmica jurídica incompatível com o

44 Esta é a posição, por exemplo, de KELSEN, exposta na Teoria pura do direito. Trad. João Batista Machado. São Paulo: Martins Fontes, 1987, p. 293-294.

45 Sobre isso, ver CATTONI DE OLIVEIRA, Marcelo Andrade. "Interpretação como ato de conhecimento e interpretação como ato de vontade: A tese kelseniana da interpretação autêntica". In Revista de Direito Comparado, Pós-Graduação em Direito/UFMG, v. 1. Belo Horizonte, 1997, p. 201-227. CARVALHO NETTO, Menelick. "A interpretação das leis: Um problema metajurídico ou uma questão essencial do Direito? De Hans Kelsen a Ronald Dworkin”. In Cadernos da Escola do Legislativo, n. 5. Belo Horizonte, 1997, p. 27-30.

46 KELSEN, Hans. Teoria pura do direito. Trad. João Batista Machado. São Paulo: Martins Fontes, 1987, p. 293. 
Estado Democrático de Direito que, fundado numa compreensão procedimentalista do Direito e da Política, não parte de um modelo fechado das normas jurídicas, mas aberto e principiológico.

E a primeira posição, pode sustentarse no marco do Estado Democrático de Direito e, portanto, no da Constituição da República brasileira? Acreditamos que sim, desde que superado o seu caráter individualista e um tanto quanto privatista.

Se, no marco do Estado Liberal, a nulidade ou nulidade absoluta de um comando inconstitucional é sanção que opera de pleno direito, em razão de um vício grave, de ordem pública, a refugir do mero interesse privado de quem quer que fosse, é compreensível a concepção segundo a qual a decisão judicial seria meramente declaratória, de reconhecimento por parte de um juiz ou tribunal de um estado de coisas já existente anteriormente à sua apreciação, assim como seria possível fundar a desobediência à esse comando em termos individualistas: quem se sentisse lesado que procurasse defender-se.

Mas tal compreensão é muito ingênua, diante da reflexividade cobrada pelo paradigma jurídico do Estado Democrático de Direito. Mas mesmo assim, é preciso reconstruir os argumentos de modo a fortalecer a primeira posição, em face, inclusive, da necessidade democrática de se fazer frente à segunda posição. Afinal, o que significaria nulidade de pleno direito, no quadro traçado da jurisdição constitucional, no exercício do controle jurisdicional de constitucionalidade, sob o paradigma do Estado Democrático de Direito?
É fundamental a relação que se estabelece entre sociedade aberta de intérpretes da Constituição e Estado Democrático de Direito. Como já avançado, sob o Estado Democrático de Direito, a jurisdição constitucional, no exercício do controle jurisdicional de constitucionalidade, deve voltar sua atuação para a garantia das condições procedimentais do exercício da autonomia por parte dos cidadãos e, com isso, garantir as condições para a realização do processo democrático, mas sem assumir a postura de um guardião da virtude, com base em fundamentos ético-culturais ou em meramente político-pragmáticos. $\bigcirc$ controle jurisdicional de constitucionalidade não pode ser tratado como um questão de Estado. É no contexto de uma esfera pública política de cidadãos os quais, no exercício de seus direitos fundamentais, aprofundam o seu sentimento de Constituição e de Democracia, que a jurisdição constitucional deve ser exercida.

Com base nesse paradigma jurídicodemocrático é que se pode dizer que todos os cidadãos têm o direito, desde que discursivamente fundados, de desobedecer a um comando normativo que considerem inconstitucional. Só assim poderá ser compreendida, hoje, a expressão nulidade de pleno direito, declarada judicialmente, fruto de um processo de reconhecimento público que, tendo por base a sociedade civil, gera influência política através dos diversos espaços públicos e transforma-se em poder político, ao ganhar os canais institucionais no interior do Poder Judiciário.

E como pode ser compreendida a afirmação segundo a qual a natureza da 
decisão jurisdicional é declaratória e não constitutiva? Ela é o reconhecimento formal ou a formalização de uma opinião pública segundo a qual as razões para desobedecer demonstraram-se constitucionalmente fundadas. E quando não forem, os desobedientes civis não deverão ser tratados como criminosos, até mesmo porque, um dia, em razão da própria dinâmica da interpretação constitucional, a posição deles pode democraticamente vir a prevalecer.

A decisão é de eficácia retroativa, ou seja, vem formalizar, institucionalizar, o reconhecimento público da invalidade da norma, que se deu na esfera pública informal ou até mesmo no plano da Administração Pública.

Tal perspectiva pode ser válida para as decisões jurisdicionais tomadas através do controle por via principal, desde que, por um lado, seja repensado o conceito processual de partes, assim como o de legitimação processual. ${ }^{47}$ Os legitimados pela Constituição, em seu art. 103, representam a cidadania.

A extensão da incidência dos efeitos retroativos sobre os atos singulares praticados com base em comando inconstitucional deve ser analisada caso a caso, segundo a lógica argumentativa dos discursos de aplicação jurídica. Para isso, seria adequado, por um lado, procurar tratar a ação direta de inconstitucionalidade no quadro geral das chamadas ações coletivas e, por outro, reconhecer, como veremos, a inconstitucionalidade da Lei $\mathrm{n}^{\mathrm{O}}$ 9.868/ 99.

Como o processo jurisdicional da ação direta de inconstitucionalidade é es pecial em face do processo jurisdicional do controle incidental, esse, sim, é o ordinário, possível de ser realizado, em princípio, em face de qualquer demanda, por qualquer juiz ou tribunal, por provocação das partes ou mesmo ex officio. Enquanto tal, aquilo que a Constituição, em primeiro lugar, e o Código de Defesa do Consumidor combinado com a Lei da Ação Civil Pública, em segundo lugar, não excepcionam, quanto aos legitimados para a propositura, quanto ao modo processual e quanto aos atingidos pela coisa julgada, vale para a ação direta de inconstitucionalidade, como vimos, o que vale para o controle incidental. A ação direta de inconstitucionalidade é uma ação coletiva, proposta, como a ação civil pública, por representantes da cidadania em geral. ${ }^{48}$

Após a análise das duas primeiras posições, a terceira fica prejudicada, pelo fato de buscar conciliar duas concepções que partem de paradigmas jurídicos diferentes, o que nada contribui para uma compreensão adequada do controle jurisdicional de constitucionalidade das leis e do processo legislativo.

47 GONÇALVES, Aroldo Plínio. Técnica processual e teoria do processo. Rio de Janeiro: Aide, 1992.

48 Essa é uma questão que pretendemos desenvolver em estudo posterior. 


\section{A inconstitucionalidade da}

Lei Federal no 9.868 e a

interpretação

constitucionalmente

adequada dos efeitos

temporais das decisões do

Supremo Tribunal Federal

em sede de ação direta de inconstitucionalidade

Em 10 de novembro de 1999 foi promulgada a Lei Federal no 9.868, que "Dispõe sobre o processo e julgamento da ação direta de inconstitucionalidade e da ação declaratória de constitucionalidade perante o Supremo Tribunal Federal”.

Tal Lei, que só recentemente vem merecendo a atenção dos magistrados, dos membros do Ministério Público e de doutrinadores pátrios, pretende introduzir uma série de inovações no sistema de controle de constitucionalidade brasileiro, alterando-lhe, profundamente, a feição, principalmente no que se refere aos efeitos temporais das decisões do Supremo Tribunal Federal, em sede do controle por via principal.

Essas inovações, com certeza, merecem não somente a atenção dos operadores jurídicos, mas também a da cidadania em geral, em razão das conseqüências nefastas advindas dos princípios subjacentes à sua adoção.

O art. 27, da referida Lei, dispõe:

"Ao declarar a inconstitucionalidade de lei ou ato normativo, e tendo em vista razões de segurança jurídica ou de excepcional interesse social, poderá o Supremo Tribunal Federal, por maioria de 2/3 (dois terços) de seus membros, restringir os efeitos daquela declaração ou decidir que ela só terá eficácia a partir do trânsito em julgado ou de outro momento que venha a ser fixado."

Como se pode depreender da análise desse dispositivo, a Lei no 9.868/99 visa atribuir ao Supremo Tribunal a competência para determinar, com força vinculante e eficácia orga omnes (nos termos do parágrafo único do seu art. 28), o momento em que suas decisões, em sede do controle por via principal, irão entrar em vigor. Assim, o Tribunal poderia modular os efeitos temporais de suas decisões, definindo a partir de quando uma lei ou ato normativo inconstitucional perderia sua eficácia, se após o trânsito em julgado da decisão, ou até mesmo no momento que se julgar conveniente, "tendo em vista razões de segurança jurídica ou de excepcional interesse social". Conseqüência mínima disso é que mesmo declarados inconstitucionais um ato normativo ou uma lei, o Supremo Tribunal Federal poderia exigir o seu cumprimento pelos demais órgãos do Poder Judiciário, pelo Poder Executivo e pela cidadania em geral.

Sabemos que não somente por razões históricas mas também sistemáticas a tradição da jurisprudência constitucional brasileira é a de que mesmo em sede de ação direta os efeitos temporais da decisão que declara a inconstitucionalidade de lei ou de ato normativo são retroativos. Como vimos, segundo esse entendimento constitucionalmente adequado ao modelo brasileiro de controle de constitucionalidade, a lei ou o ato normativo inconstitucional é uma contradição em termos, pois todo ato de von- 
tade, emanado do Legislativo ou do Executivo, que fere, formal ou materialmente, a Constituição, carece de seu fundamento de validade, e, por isso, embora exista como ato de vontade, não existe como lei ou ato normativo, como ato dotado de normatividade, de obrigatoriedade.

Nesse sentido, um ato inconstitucional nunca vinculou o Judiciário e a Administração e, muito menos, os cidadãos, que têm o direito fundamental a não se submeterem a comandos inconstitucionais.

Mesmo após a introdução da via principal de controle, considera a jurisprudência que o sistema permanece eminentemente difuso (procedimento ordinário de controle), devendo o processo e o julgamento da ação direta submeterem-se aos princípios assentados jurisprudencialmente.

Todavia, desde a República Velha, vozes já se levantavam contra o sistema difuso e, num nível pragmático, buscavam alertar para o que seria o risco de decisões contraditórias, na medida em que as decisões judiciais brasileiras, diferentemente das norte-americanas, não possuiriam efeito vinculante, nem fariam precedente obrigatório.

Progressivamente, foram inseridos mecanismos que teriam a finalidade de suprir o que seria uma deficiência do sistema brasileiro, a começar pela possibilidade do Senado retirar do quadro das leis uma lei declarada inconstitucional, em última instância, pelo Supremo Tribunal, até a introdução do controle por via principal e, agora, a com a atribuição de efeito vinculante às decisões desse Tribunal em matéria constitucional.
Cada vez mais, à retórica das decisões contraditórias acrescentam-se outros argumentos metodológicos e pragmáticos acerca do controle de constitucionalidade. Primeiramente, argumenta-se, com base sobretudo em KELSEN, que não se pode sustentar a tese da nulidade absoluta ou de pleno direito da lei inconstitucional; o Direito moderno é caracterizado por sanções organizadas que não se aplicam automaticamente, não se podendo confundir o vício da inconstitucionalidade com a sanção de nulidade.

As conseqüências tiradas dessas afirmações seriam, primeiramente, a de que não haveria nenhuma questão de princípio que se pudesse reconhecer a fim de se concluir que uma decisão que anule uma norma inconstitucional o faria sempre com caráter retroativo. A lei é presumida constitucional até que órgão competente, exercendo o papel de legislador negativo, a considere inconstitucional e a anule. Segundo, seria o Direito Positivo que definiria o aspecto temporal dos efeitos da decisão ou, na ausência de norma expressa, o próprio órgão, discricionariamente. E, terceiro, caberia tão-somente ao órgão competente anular a lei, centralizando a autorização para aplicar a sanção, não assistindo aos cidadãos um direito à desobediência: como vimos, em termos kelsenianos, quem não cumprir uma lei por considerá-la inconstitucional assim o faria por sua conta e risco, já que o órgão competente poderia considerar a lei constitucional.

Além dos argumentos metodológicos, e da já tradicional retórica das decisões contraditórias, acrescentaram-se outros de caráter pragmático. $\bigcirc$ esquema tradicional do 
controle não se adaptaria às necessidades do Estado Social. Seria necessário modular os efeitos temporais da decisão constitucional, em razão dos novos fins e tarefas assumidos pelo Estado. A técnica da declaração de inconstitucionalidade não seria adequada a um sistema jurídico que estabelecesse programas a serem progressivamente implementados ou que possibilitariam a sua aplicação em diversos graus. Ou seja, a própria distinção constitucionalidade/inconstitucionalidade deveria, assim, ser revista, pois não consideraria situações intermediárias, tais como as de omissões parciais do legislador. ${ }^{49}$ Esse argumento, inclusive, é explicitamente apresentado pela Comissão especial que redigiu o anteprojeto que mais tarde veio a servir de base para a Lei no 9.868/99.50

Uma vez que já tratamos, anteriormente, a questão acerca da justificação do controle de constitucionalidade, assim como acerca da caracterização constitucionalmente adequada dos efeitos temporais das decisões jurisdicionais em matéria constitucional no Brasil, poderemos analisar o que poderá significar, para o sistema jurídico brasileiro, a inclusão dos dispositivos previstos pela Lei no 9.868/99, assim como a questão acerca de se esses dispositivos são constitucionais, à luz de uma compreensão constitucionalmente adequada do controle de constitucionalidade.

A inclusão de tais dispositivos representa a tentativa de uma alteração do siste- ma de controle jurisdicional de constitucionalidade das leis e de atos normativos que, todavia, fere o modelo constitucionalmente previsto.

Ao atribuir ao Supremo Tribunal Federal a competência para modular os efeitos de suas decisões, em sede do controle por via principal, admitindo a eficácia ex nunc, ao atribuir natureza constitutiva à decisão, assim como a possibilidade de que esta passaria a gerar efeitos quando o Tribunal assim o determinar, o art. 27, da Lei no 9.868/99 fere uma interpretação constitucionalmente adequada de uma série de dispositivos constitucionais, dentre eles:

1. o princípio do Estado Democrático de Direito, fixado no art. $1^{\mathrm{O}}$;

2. a aplicação imediata dos direitos fundamentais, $\S 1^{\mathrm{O}}$, art. 5웅

3. a imutabilidade dos princípios constitucionais, no que concerne aos direitos fundamentais e ao processo especial de reforma da Constituição, art. 5으, $\$ \S 1^{\circ}$ e e 2우 art. 60, $\$ 4^{\text {o}}$;

4. o sistema ordinário de controle jurisdicional difuso da constitucionalidade, art. 97 e art. 102, III, $a, b$ e c, que atribui competência a todo juiz ou tribunal para deixar de aplicar a lei inconstitucional, assim como o direito que dele decorre ao cidadão de se recusar a cumprir a lei inconstitucional, assegurando-se-lhe, em

49 MENDES, Gilmar Ferreira e MARTINS, Ives Gandra da Silva. Controle concentrado de constitucionalidade: Comentários à Lei $n^{-0}$ 9.878 , de 10.11.1999. São Paulo: Saraiva, 2001. Para nós, esse argumento não procede à luz de uma concepção contrutiva da interpretação constitucional: o caso seria de se aplicar o princípio constitucional da igualdade e não simplesmente o de declarar, negando tutela jurisdicional adequada, uma omissão parcial.

MENDES, Gilmar Ferreira. Jurisdição constitucional. São Paulo: Saraiva, 1999, apêndice. 
última instância, a possibilidade de interpor recurso extraordinário ao Supremo Tribunal Federal contra decisão judicial que se apresente contrária à Constituição, nos termos do art. 102, III, $a$.

Como bem assinalava, inclusive, GILMAR FERREIRA MENDES, em sua Tese de Doutorado,

"Tanto o poder do juiz de negar aplicação à lei inconstitucional quanto a faculdade assegurada ao indivíduo de negar observância à lei inconstitucional demonstram que o constituinte pressupôs a nulidade da lei inconstitucional. Nessa medida, é imperativo concordar com a orientação do STF que parece reconhecer hierarquia constitucional ao postulado da nulidade da lei incompatível com a Constituição." 51

Por fim, cabe analisar um argumento que vem sendo apresentado por defensores da constitucionalidade da Lei no 9.868/99, fundado numa determinada compreensão dos princípios constitucionais, desenvolvida por autores vinculados à chamada jurisprudência dos valores. Essa posição não nega a hierarquia constitucional do princípio da nulidade da lei inconstitucional, mas acredita que, sendo os princípios mandatos de otimização (ALEXY), esses terão sua aplicação sujeita a um princípio de ponderação, segundo o qual os princípios se diferenciariam das regras justamente porque, ao lado de questões de validade, colocariam questões de peso, podendo, portanto, serem aplicados em diferentes graus, segundo circunstâncias fáticas e ju- rídicas (ALEXY). Assim, uma vez que também se reconhecesse status constitucional às razões de segurança jurídica e de relevante interesse social, o princípio da nulidade da lei inconstitucional incorreria numa operação de sopesamento, que envolveria tais razões, e teria a sua aplicação afastada se, em face de um processo específico de controle concentrado, tais razões encontrassem maior relevância do que a simples declaração de nulidade, com efeitos ex tunc.

A questão é que essa posição não leva a sério o caráter especificamente deontológico dos princípios constitucionais. Os princípios, enquanto normas, diferenciamse dos valores justamente porque estabelecem um vínculo de obrigatoriedade e não da preferência ou de conveniência. Princípios estabelecem o que é devido e não o que é preferível. Enquanto tal, possuem um código binário e não gradual, não podendo ser cumpridos em maior ou menor extensão.

Outro problema dessa concepção é o de confundir a perspectiva argumentativa do processo jurisdicional com a perspectiva argumentativa do processo legislativo. Enquanto nesse último se colocam questões que venham, justamente, a justificar a validade das normas, naquele se coloca a questão acerca da adequabilidade de uma norma à solução de um caso concreto. Dizer que os princípios se distinguem das regras por eles colocam, em seu processo de aplicação, questões de ponderação ao lado de questões de validade, que lhe possibilitam um 
cumprimento gradual, nada diz acerca da sua adequabilidade.

Ao final, ao se reduzir o Direito a valores que, por sua natureza, não são homogêneos numa mesma sociedade, aumenta-se o risco da irracionalidade do processo jurisdicional de controle, transformando-o, em uma instância político-legislativa que se sobressairia ao próprio legislador democrático. Instaurar-se-ia, desse modo, uma ditadura de boas intenções éticas e políticas que desrespeita a cidadania e o legislativo, à medida que os reduz a meros tutelados do Tribunal de cúpula ou, no caso alemão, da Corte Constitucional.

Como exaustivamente afirmado, embora a tarefa de garantir as condições processuais para o exercício das autonomias pública e privada dos cidadãos necessite de uma jurisdição constitucional ofensiva, nos casos em que se deve impor o processo democrático e a forma deliberativa da formação política da opinião e da vontade, isso não pode fazer da jurisdição constitucional uma guardiã republicana do processo político e da cidadania. Uma interpretação do processo político, que seja adequada à complexidade das sociedades atuais, não pode reduzir a política a um processo de autorealização ética, nem muito menos reduzir a Constituição a uma ordem concreta de valores. A formação democrática da vontade e da opinião, ao contrário do que pressupõe a tradição republicana, não tira sua força legitimadora da convergência de convicções e de razões éticas, mas dos pressupostos comunicativos e dos processos de justificação normativa que possibilitam o aporte de razões e interesses de amplo espectro, de tal modo a possibilitar a seleção dos melhores argumentos. A autonomia pública, assim como o Direito, não pode ser reduzida a uma auto-realização ética, o que justifica, segundo HABERMAS, o fato de a Teoria do Discurso não precisar revestir o processo político de condições excepcionais de consciência e de virtude cívicas. ${ }^{52}$ Assim, a jurisdição constitucional não tem, portanto, que buscar sua legitimidade em condições excepcionais. Ela pode permanecer no quadro de sua autoridade para aplicar o Direito, na certeza de que o processo democrático, que ela deve proteger, não precisa ser descrito como um estado de exceção.

É um imperativo reconhecer, portanto, a inconstitucionalidade da Lei n⿳0 9.868/ 99 , que pretende descaracterizar o controle difuso, ao buscar alterar o artigo 482 do Código de Processo Civil, e por intentar transformar as decisões em ação direta de inconstitucionalidade perante o Supremo Tribunal Federal num meio espúrio de suspensão da ordem constitucional, ao pretender atribuir ao Supremo o poder de restringir o conteúdo e de fixar os efeitos temporais de suas decisões, flagrantemente invertendo a hierarquia das fontes do Direito, ao poder determinar, à cidadania, à Administração

52 A crítica se destina diretamente tanto a BRUCE ACKERMAN e seu modelo dualista de democracia, quanto a FRANK MICHELMAN e sua caracterização do papel da Suprema Corte norte-americana, mas pode estender-se ao republicanismo em geral. Assim, afirma HABERMAS, Direito e democracia, v. 1, p. 345, que: "A tradição republicana sugere um tal excepcionalismo, uma vez que liga a prática política dos civis ao ethos de uma comunidade naturalmente integrada. A política correta só pode ser feita por (cidadãos) virtuosos". 
Pública e aos demais juízes e tribunais, a obediência a leis e atos normativos declarados inconstitucionais pelo próprio Tribunal, com base em "razões (?) de segurança jurídica ou de excepcional interesse social" (art. 27, da Lei no 9.868/99).

Cabe concluir, enfim, com a seguinte advertência: Se do ponto de vista da reconstrução teorético-histórica e sociológica se pode dizer que a jurisdição constitucional, no marco do paradigma do Estado Social, tenha agido como legislador concorrente ou ao menos subsidiário, tal compreensão não é correta, quer do ponto de vista teorético-filosófico adequado ao paradigma do Estado Democrático de Direito, aqui, adotado, quer de um ponto de vista teórico-dogmático adequado ao Direito Constitucional brasileiro. Assim, o exercício da jurisdição constitucional, sob o risco de afetar a democracia, o pluralismo e os direitos fundamentais, não deve assumir, do ponto de vista argumentativo da aplicação jurídica no Estado Democrático de Direito, uma posição de poder legislativo, concorrente ou subsidiário, e muito menos de poder constituinte permanente. 